\title{
Classification and ordination of vegetation in Tehsil Takht-e-Nasrati, District Karak, Khyber Pakhtunkhawa, Pakistan
}

\author{
Musharaf Khan* and Farrukh Hussain \\ Department of Botany, University of Peshawar, Pakistan.
}

Accepted 22 March, 2013

\begin{abstract}
A survey of natural vegetation of semi arid area was undertaken in 2010-2011. The study was conducted within four distinct stands further divided into 22 sites for clear communities' segregation. Hierarchical Cluster Analysis (HCA) and Detrended Correspondence Analysis (DCA) were used for the plant species and community analysis. Plant species of each community are presented together with the information on dominance and sub-dominance species. Five plant association, that is, Cenchrus-SaccharumProsopis association, Cenchrus-Eragrostis-Calligonum association, Zizyphus-Cenchrus-Eragrostis association, Rhazya-Fagonia-Cymbopogon association and Aerua-Boerhavia-Zizyphus association were recognized on the basis of communities and plant species gave rise to 5 groups. The average highest important value was initiated in Zizyphus maurtiana (23.7), Cenchrus biflorus (23) and Eragrostis poaoides (21.4). Classification and ordination techniques provided very similar results based on the floristic composition and communities similarity. The results produced the source for the mapping division of plant communities.
\end{abstract}

Key words: Hierarchical cluster analysis (HCA), detrended correspondence analysis (DCA), distribution patterns, plants association, summer, Pakistan.

\section{INTRODUCTION}

Ordination techniques are commonly used in phytosociology. This may be done either by arranging the points along the axis or by forming the scatter diagram with two or more axis. Detrended Correspondence Analysis (DCA) is an indirect gradient analysis technique in which the distribution of species is not controlled by environmental variables rather, it focuses on analyzing the pattern of species distribution. Environmental data for DCA is not required and species data is used to assume the gradients (Sagers and Lyon, 1997). Ordination techniques are widely used by the ecologists to study the relationship between vegetation and environment. Khaznadar et al. (2009) conducted a study in Chott El Beida wetland, a RAMSAR site in Setif, Algeria to study distribution of plants community and environmental factors. The collection was done from sixty vegetation plots. TWINSPAN and DCA were used as the analysis techniques. A similar study was conducted by Ahmad et al. (2010) along motorway (M-2), Pakistan using multivariate techniques, that is, DECORANA. Results showed two major and sixteen sub-communities from 397 quadrats. The study was helpful for implementation and conservation planning and for the improvement of road sides. To study the relationship between vegetation and environment, a study was conducted by $\mathrm{He}$ et al. (2007) in the Alxa Plateau of Inner Mongolia, China which resulted in the detection of six characteristics vegetation groups by using the DCA. Ahmad (2009) studied the herbaceous vegetation in Margalla Hills National Park, Islamabad, Pakistan. Four vegetation groups were recognized by TWINSPAN. ElBana et al. (2009) studied Juniperus phoenicea L. and associated vegetation at three mountains in Egypt, 
resulting in the recognition of four vegetation types along with juniper by TWINSPAN and DCA analysis techniques. Jabeen and Ahmad (2009) conducted a study to analyze the vegetation and environment data of Ayub National Park, Rawalpindi. PCOrd 5 and CANOCO 4.5 were used and data was recorded by quadrat method. 44 plants species from 30 quadrats were recorded. Many researchers (Dasti and Malik, 1998; Malik and Hussain, 2008; Saima et al., 2009; Ahmad, 2009; Ali and Malik, 2010; Ahmad et al., 2010) have studied different aspects of vegetation structure and classification and ordination distribution patterns in different parts of Pakistan. Classification and ordination is an invaluable method for vegetation survey and assessment involving investigation of characteristics of plant communities using simple and rapidly employing field techniques (El-Ghanim et al., 2010). In the present study, an effort has been made to investigate and analyse correlation of communities with key environmental factors. The Tehsil Takht-e-Nasrati comprises one of the richest and most interesting ecosystems on earth. The community structure and distribution patterns of research area have not been given due attention till date by the plant ecologists, and hence poorly understood (Khan, 2012). The particular objectives of the present study include quantifying the vegetation in summer of Tehsil Takht-e-Nasrati, District Karak using ordination techniques for upcoming conservation and providing base line data of ecological important area.

\section{MATERIALS AND METHODS}

\section{Study area}

The Tehsil Takhti Nasratti is situated at $32.47^{\circ}$ to $33.28^{\circ}$ North and $70.30^{\circ}$ to $71.30^{\circ}$ East. The Tehsil is bounded by Tehsil Banda Dawood Shah on the North West, Tehsil Karak on the North East, District Mianwali and District Lakki Marwat on the South East, and Tribal area Adjoining District Bannu on the South West (Figure 1). The total area of Tehsil is about 613.66 sq. km. Majority of the area consists of rigged dry hills and rough fields areas, that is, 323.97 sq. $\mathrm{km}$ and agriculture land is about $289.7 \mathrm{sq} . \mathrm{km}$. The major income source of the people is agriculture, which is rain depended. The area is situated at $340 \mathrm{~m}$ above the sea level. Environmental data showed that mean air temperature was high in the month of June $\left(39.5^{\circ} \mathrm{C}\right)$ and low in the month of September $\left(21.95^{\circ} \mathrm{C}\right)$, relative humidity was high $(77.21 \%)$ in the month of September and low $(30.73 \%)$ in May, rainfall $(121.6 \mathrm{~mm})$ was high in July and low (31.6 $\mathrm{mm}$ ) in May, soil temperature $\left(26.77^{\circ} \mathrm{C}\right)$ was high in July, wind speed was high in June $(5.5 \mathrm{Km} / \mathrm{h})$ and low $(3.7 \mathrm{~km} / \mathrm{h})$ in September, which indicated dry condition during summer. Summer season started from May to September in the area and 11 plant communities were recognized in plains. The investigated area shows altitudinal variation, that is, from 340 to $500 \mathrm{~m}$. This also caused deviation in plant life structure (Table 1).

\section{Data collection}

Floristic data were collected from 22 randomly selected sites from 4 stand selected on the basis of altitude. Quadrat method was used for the collection of vegetation data. Each field site comprised of 10 quadrats for each plant layer, that is, tree $(10 \times 10 \mathrm{~m})$, shrubs $(5 \times 5$ $\mathrm{m})$ and herbs $(1 \times 1 \mathrm{~m})$. The latitude and longitudes were recorded for each site using a Global Positioning System (GPS). Sampling was completed in summer season. The summer season starts in June to August. Collected samples were pressed, dried and transported to the herbarium, Department of Botany, University of Peshawar, Khyber Pakhtunkhawa, Pakistan, where they were identified and classified following Stewart (1972) and Nasir and Ali (1972) and a fraction of angiosperms of Tehsil Banda Daud Shah by Khan (2004).

\section{Data analysis}

Vegetation attributes including frequency, density and cover were recorded along with environmental coordinates like latitude, longitude, altitude and slope using GPS. The importance value of each species was compiled adding RD, RF and RC following Hussain (1989). On the basis of the highest importance values of the first three dominant species from each layer, the communities were established and named. All the species data, as well as all communities were used for the analysis. The data was classified using standard methods Hierarchical Cluster Analysis (HCA) and DCA (Hill, 1979) to summarize biological records and position of plants and communities in groups during summer. The plant life associations were named after the highest value of three dominant species. DCA ordination offered two significant ordination axes on the basis of weight for plant species and communities. DCA were performed to describe compositional gradients in the vegetation. All analysis was performed using the software PCORD ver. 4.16 (McCune and Mefford, 1999).

\section{RESULTS}

The arrangement of plant life record is commonly vegetation orientation and main question concern the classification and explanation of the vegetation in addition to inconsistency of ecological arrangement. Distinctive multivariate techniques are generally fruitful and commonly used for plant life arrangement. Though, distinctive multivariate analyses do not directly explain relations in their computation, they are not particularly designed to vegetation structures rationalization. The ordination may be defined as the position of communities designed to set apart group types, location, relative position, standing of communities in a season of particular area. In other words, the ordination is the sound or clear arrangement of split communities or species in a season of a particular area. In the present work, the ordination of communities in summer is given as follows:

\section{Hierarchical cluster analysis}

Twenty two communities were analyzed for ordination by cluster analysis and DCA. The hierarchical cluster analysis shows that the relationship among 22 communities were inclusive in 21 cluster cycling where in as $0.66 \%$ chaining. Furthermore, it marked out different five groups by different level, cycling and similarity of communities. The average highest important value was initiated in Zizyphus maurtiana (23.7) in group B, Cenchrus biflorus (23) in group D and Eragrostis poaoides (21.4) in group 


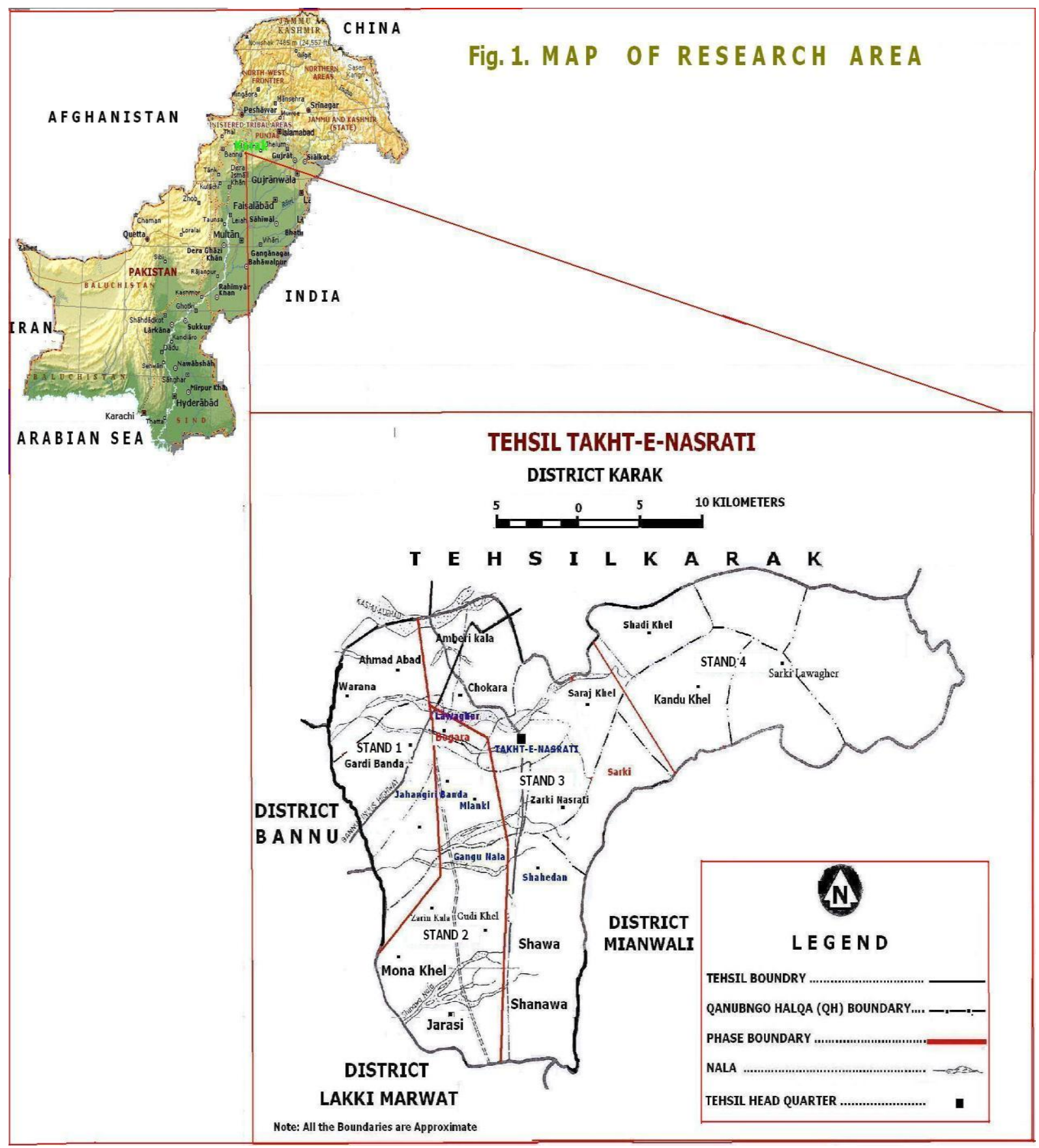

Figure 1. Map of Tehsil Takht-e-Nasrati, District Karak, showing research spots.

E. The picture of each one group association is as below:

\section{Cenchrus-Saccharum-Prosopis association}

The group 1 consists of Eragrostis-Calotropis-Prosopis community (ECP), Phoenix- Saccharum-Cenchrus community (PSC), Aerua-Prosopis-Saccharum community (APS) and Tribulus-Tamarix-Saccharum community (TTS) which raised at $1.5117 \mathrm{E}+00$ in cycles 14 . It composed of
28 plant species consisting of 6 trees, 6 shrubs and 16 herbs. The dominant plant species on the basis of important value were $C$. biflorus (IV $=29.2$ ), Saccharum bengalense (IV $=25.5$ ) in group $\mathrm{D}$ while Prosopis farcta (IV = 24.3) in group A (Table 2; Figures 2 and 3).

\section{Cenchrus-Eragrostis-Calligonum association}

Group 2 consists of 26 species of 4 tree, 5 shrubs and 17 
Table 1. Meteorological data of Tehsil Takht-e-Nasrati, District Karak for the year 2001-2010.

\begin{tabular}{|c|c|c|c|c|c|c|c|}
\hline \multirow{2}{*}{ Month } & \multicolumn{2}{|c|}{ Temperature $\left({ }^{\circ} \mathrm{C}\right)$} & \multicolumn{2}{|c|}{ Humidity (\%) } & \multirow{2}{*}{$\begin{array}{c}\text { Rainfall } \\
(\mathrm{mm})\end{array}$} & \multirow{2}{*}{$\begin{array}{c}\text { Soil temperature } \\
\left({ }^{\circ} \mathrm{C}\right) \text { average }\end{array}$} & \multirow{2}{*}{$\begin{array}{c}\text { Wind speed (km } \\
\text { per hour) }\end{array}$} \\
\hline & Max & Min & Max & Min & & & \\
\hline January & 19.18 & 4.26 & 75.80 & 35.24 & 27.43 & 7.03 & 2.9 \\
\hline February & 21.69 & 7.29 & 77.39 & 42.23 & 37.72 & 9.14 & 3.2 \\
\hline March & 28.20 & 12.06 & 75.38 & 35.23 & 37.17 & 13.89 & 3.5 \\
\hline April & 34.74 & 17.94 & 66.12 & 29.42 & 36.54 & 19.02 & 5.2 \\
\hline May & 38.32 & 22.33 & 59.66 & 30.73 & 31.6 & 21.87 & 5.4 \\
\hline June & 39.50 & 25.9 & 59.96 & 32.89 & 74.24 & 25.78 & 5.5 \\
\hline July & 38.44 & 25.76 & 73.33 & 38.76 & 121.6 & 26.77 & 5.2 \\
\hline August & 36.66 & 25.29 & 75.68 & 42.61 & 108.3 & 26.37 & 4.1 \\
\hline September & 35.47 & 21.95 & 77.21 & 39.29 & 61.58 & 23.49 & 3.7 \\
\hline October & 32.33 & 16.79 & 71.55 & 35.51 & 15.13 & 20.09 & 3.5 \\
\hline November & 26.71 & 10.01 & 71.56 & 36.66 & 5.80 & 14.10 & 3.2 \\
\hline December & 21.93 & 5.67 & 75.20 & 35.90 & 15.38 & 8.96 & 3.1 \\
\hline Mean & 31.1 & 16.27 & 71.57 & 36.21 & 47.71 & 18.04 & 4.04 \\
\hline
\end{tabular}

Source: Agricultural Research Farm, Ahmad Wala Karak.

herbs. Eragrostis-Saccharum-Zizyphus community (ESZ), Calligonum-Cenchrus-Zizyphus community (CCZ), Tribulus-Acacia-Saccharum community (TAS) and Calligonum-Tribulus-Zizyphus community (CTZ) made the association at $6.2210 \mathrm{E}-01$ in cycles 8 . The mean highest important value was covered by $C$. biflorus (IV = 29.7 ) in group $D, E$. poaoides (IV = 26.6) in group $E$ and Calligonum polygonoides (IV $=26.14$ ) in group C (Table 2; Figures 2 and 3).

\section{Zizyphus-Cenchrus-Eragrostis association}

Zizyphus-Cenchrus-Saccharum community (ZCS), Saccharum-Zizyphus-Cynodon community (SZC) and Eragrostis-Zizyphus-Capparis community (EZC) formed the $3^{\text {rd }}$ group of association at $8.7080 \mathrm{E}-01$ in cycles 10 . It composed of 27 species including 3 tree, 9 shrub and 15 herb species. The dominant plant of association were $Z$. maurtiana (IV $=51.25$ ) in group $\mathrm{B}, \mathrm{C}$. biflorus $(\mathrm{IV}=33.88)$ in group $\mathrm{D}$ and $E$. poaoides in group $E(I V=32.44)$ (Table 2; Figures 2 and 3).

\section{Rhazya-Fagonia-Cymbopogon association}

Rhazya Fagonia Cymbopogon association becomes visible in the form of 4th group at $1.9213 \mathrm{E}+00$ in cycle 16 that consists of 5 communities, that is, CymbopogonRhazya-Zizyphus community (CRZ), Fagonia-RhazyaZizyphus community (FRZ), Cenchrus-Cassia-Zizyphus community (CCZ), Cleome-Phoenix-Capparis community (CPC) and Tribulus-Periploca-Zizyphus community (TPZ). The mean highest IV was attained by Rhazya stricta (IV = 32) and Cymbopogon jwarancusa (IV = 25.7) in group E while Fagonia cretica (IV $=29.2$ ) in group B. Moreover, 33 plants consisted of 7 tree, 10 shrub and 16 herb spe- cies (Table 2; Figures 2 and 3).

\section{Aerua-Boerhavia-Zizyphus association}

Saccharum-Cymbopogon-Zizyphus community (SCZ), Capparis-Aerua-Acacia community (CAA), Aerua-AcaciaCapparis community (AAC), Boerhavia-Acacia-Capparis community (BAC) and Boerhavia-Zizyphus-Capparis community (BZC) formed group 5 at $2.1408 \mathrm{E}+00$ during cycle 17. It composed of 26 species containing 5 trees, 9 shrubs and 12 herbs. The mean highest IV represented by Aerua persica and $Z$. maurtiana were 41.8 and 21.87 in group B while Boerhavia diffusa (IV = 26.5) was in group C. (Table 2; Figures 2 and 3).

\section{Detrended Correspondence Analysis (DCA)}

Ordination of the communities in summer by DCA explains that 5 groups, that is, 1, 2, 3, 4 and 5 on the basis of DCA weight on Axis 1 and 2, with different weight were formed and comprises 5, 3, 2, 5 and 2 communities, respectively. On axis 1, Groups 1, 2, 3, 4 and 5 were structured with DCA mean weight 171.2, 136.7, 70, 40.3 and 14.5 at EIG 0.385 , respectively. High DCA weight (244) in BAC and low (0) in ECP was present on Axis 1. On Axis 2, the mean DCA weight of groups, that is, $1,2,3,4$ and 5 were found as $106.2,65,120,57.67$ and 5.5 , respectively, while the highest DCA weight (168) was found in ECP and lowest (0) in ZCS at EIG (0.157). The communities that were not present in any groups were BAC, BZC, CRZ, APS and ECP with DCA weight of 244, 224, 192, 64 and zero, respectively, on Axis 1. These groups showed different vegetation types during summer seasons (Figure 4). 
Table 2. Mean relative importance value of species in different community associations during summer distinguished through cluster analysis of Tehsil Takht-e-Nasrati, Karak.

\begin{tabular}{|c|c|c|c|c|c|c|c|c|}
\hline \multirow{2}{*}{ Group } & \multirow{2}{*}{\multicolumn{2}{|c|}{ Specie name }} & \multicolumn{5}{|c|}{ Association } & \multirow{2}{*}{ Average } \\
\hline & & & 1 & 2 & 3 & 4 & 5 & \\
\hline \multirow{9}{*}{ A } & Sp1 & Acacia modesta Wall. & 0 & 0 & 0 & 7.2 & 21.37 & 5.71 \\
\hline & Sp 3 & Dalbergia sissoo Roxb. & 2.32 & 5.17 & 5.91 & 0.68 & 2.01 & 3.22 \\
\hline & Sp 4 & Gymnosporia royleana Wall. ex M. A. Lawson & 0 & 0 & 0 & 0.93 & 0 & 0.19 \\
\hline & Sp 5 & Monotheca buxifolia (Falc.) A.D. & 0 & 0 & 0 & 1.09 & 0 & 0.22 \\
\hline & Sp 8 & Prosopis farcta (Banks \& Sol.) J.F. Macbr. & 24.3 & 0 & 0 & 0 & 0 & 4.86 \\
\hline & Sp 9 & Tamarix aphylla (L.) Karst. & 1.4 & 0 & 0 & 0 & 0 & 0.28 \\
\hline & Sp 16 & Cassia angustifolia Vahl. & 0 & 0 & 0 & 7.14 & 0 & 1.43 \\
\hline & Sp 34 & Cyperus esculentus $\mathrm{L}$. & 18 & 8.11 & 3.1 & 4.6 & 16.74 & 10.1 \\
\hline & Sp 35 & Cyperus rotundus $\mathrm{L}$. & 7.16 & 14.65 & 17.66 & 7.8 & 4.51 & 10.4 \\
\hline \multirow{11}{*}{ B } & Sp 10 & Zizyphus maurtiana Lam. & 12.3 & 15.68 & 51.25 & 17.6 & 21.87 & 23.7 \\
\hline & Sp 14 & Capparis decidua (Forssk.) Edge worth. & 0 & 0 & 9.3 & 7.2 & 16.11 & 6.52 \\
\hline & Sp 15 & Capparis spinosa $\mathrm{L}$. & 0 & 0 & 0 & 0 & 20.53 & 4.11 \\
\hline & Sp 25 & Zizyphus nummularia (Burm.f.) W. \& A. & 0 & 0 & 0 & 6.71 & 3.89 & 2.12 \\
\hline & Sp 26 & Aerua persica (Burm.f.) Merrill. & 16 & 2.48 & 2.31 & 4.3 & 41.8 & 13.4 \\
\hline & Sp 29 & Chrozophora obliqua (Vahl.) A. Juss. & 6.32 & 6.54 & 0 & 0 & 0 & 2.57 \\
\hline & Sp 36 & Echinops echinatus Roxb. & 0 & 5.15 & 1.48 & 3.42 & 2.22 & 2.45 \\
\hline & Sp 40 & Fagonia cretica L. & 9.66 & 7.47 & 7.96 & 29.2 & 4.6 & 11.8 \\
\hline & Sp 41 & Heliotropium europaeum L. & 8.53 & 11.61 & 0 & 2.69 & 0 & 4.57 \\
\hline & Sp 44 & Salvia moorcroftiana Wallich ex Benth. & 0 & 0 & 0 & 4.4 & 0 & 0.88 \\
\hline & Sp 46 & Tribulus terrestris $\mathrm{L}$. & 19.2 & 25.51 & 9.78 & 10.9 & 18.3 & 16.7 \\
\hline \multirow{7}{*}{ C } & Sp 2 & Acacia nilotica (L.) Delice. & 3.92 & 10.03 & 4.34 & 4.38 & 2.82 & 5.1 \\
\hline & Sp 6 & Phoenix dactylifera L. & 12.2 & 2.99 & 0 & 6.19 & 0 & 4.28 \\
\hline & Sp 12 & Calligonum polygonoides $\mathrm{L}$. & 0 & 26.14 & 3.38 & 0 & 0 & 5.9 \\
\hline & Sp 21 & Ricinus communis $\mathrm{L}$. & 2.2 & 0 & 0 & 0 & 0 & 0.44 \\
\hline & Sp 23 & Saccharum spontaneum L. & 12.6 & 0 & 0 & 5.64 & 0 & 3.65 \\
\hline & Sp 27 & Boerhavia diffusa $\mathrm{L} .$. & 8.81 & 12.69 & 16.46 & 10.8 & 26.5 & 15.1 \\
\hline & Sp 43 & Peganum hermala L. & 5.52 & 0 & 0 & 0 & 0 & 1.1 \\
\hline \multirow{8}{*}{$\mathrm{D}$} & Sp 11 & Astragalus psilocentros Fisch. & 0 & 0 & 2.07 & 0.73 & 16.14 & 3.79 \\
\hline & Sp 13 & Calotropis procera (Wild) R.Br. & 16.4 & 6.18 & 7.76 & 3.7 & 2.54 & 7.32 \\
\hline & Sp 18 & Periploca aphylla Decne. & 10.1 & 6.84 & 4.5 & 6.9 & 0 & 5.67 \\
\hline & Sp 19 & Punica granatum $\mathrm{L}$. & 0 & 0 & 0 & 0 & 7.74 & 1.55 \\
\hline & Sp 22 & Saccharum bengalense Retz. & 25.5 & 18.02 & 22.66 & 3.37 & 11.4 & 16.2 \\
\hline & Sp 24 & Withania coagulans (Stocks) Dunal. & 0 & 0 & 0.91 & 10.8 & 1.79 & 2.7 \\
\hline & Sp 28 & Cenchrus biflorus Hook. f. & 29.2 & 29.7 & 33.88 & 15.7 & 6.7 & 23 \\
\hline & Sp 45 & Solanum surattense Burm .f. & 3.04 & 1.63 & 5.81 & 11.9 & 3.52 & 5.18 \\
\hline \multirow{11}{*}{ E } & Sp 7 & Prosopis juliflora (Sw.) DC. & 0 & 0 & 0 & 0 & 1.04 & 0.21 \\
\hline & Sp 17 & Datura metel L. & 6.22 & 1.72 & 4.22 & 0 & 0 & 2.43 \\
\hline & Sp 20 & Rhazya stricta Decne. & 0 & 0 & 2.98 & 32 & 9.52 & 8.9 \\
\hline & Sp 30 & Citrullus colocynthis L. Schrad. & 0 & 6.91 & 9.06 & 0 & 0 & 3.19 \\
\hline & Sp 31 & Cleome viscosa $\mathrm{L}$. & 0 & 0 & 0 & 8.13 & 0 & 1.63 \\
\hline & Sp 32 & Cymbopogon jwarancusa (Jones) Schult. & 0 & 5.12 & 0 & 25.7 & 10.33 & 8.23 \\
\hline & Sp 33 & Cynodon dactylon (L.) Pers. & 5.6 & 5.7 & 13.86 & 15.1 & 18.17 & 11.7 \\
\hline & Sp 37 & Eragrostis poaoides Beauv. & 22.4 & 26.6 & 32.44 & 17.5 & 7.84 & 21.4 \\
\hline & Sp 38 & Euphorbia hirta L. & 7.3 & 21.49 & 9.01 & 0 & 0 & 7.56 \\
\hline & Sp 39 & Euphorbia prostrata Ait. & 3.8 & 15.87 & 14.38 & 5.6 & 0 & 7.93 \\
\hline & Sp 42 & Launaea nudicaulis (L.) Hook. f. & 0 & 0 & 3.53 & 0 & 0 & 0.71 \\
\hline
\end{tabular}




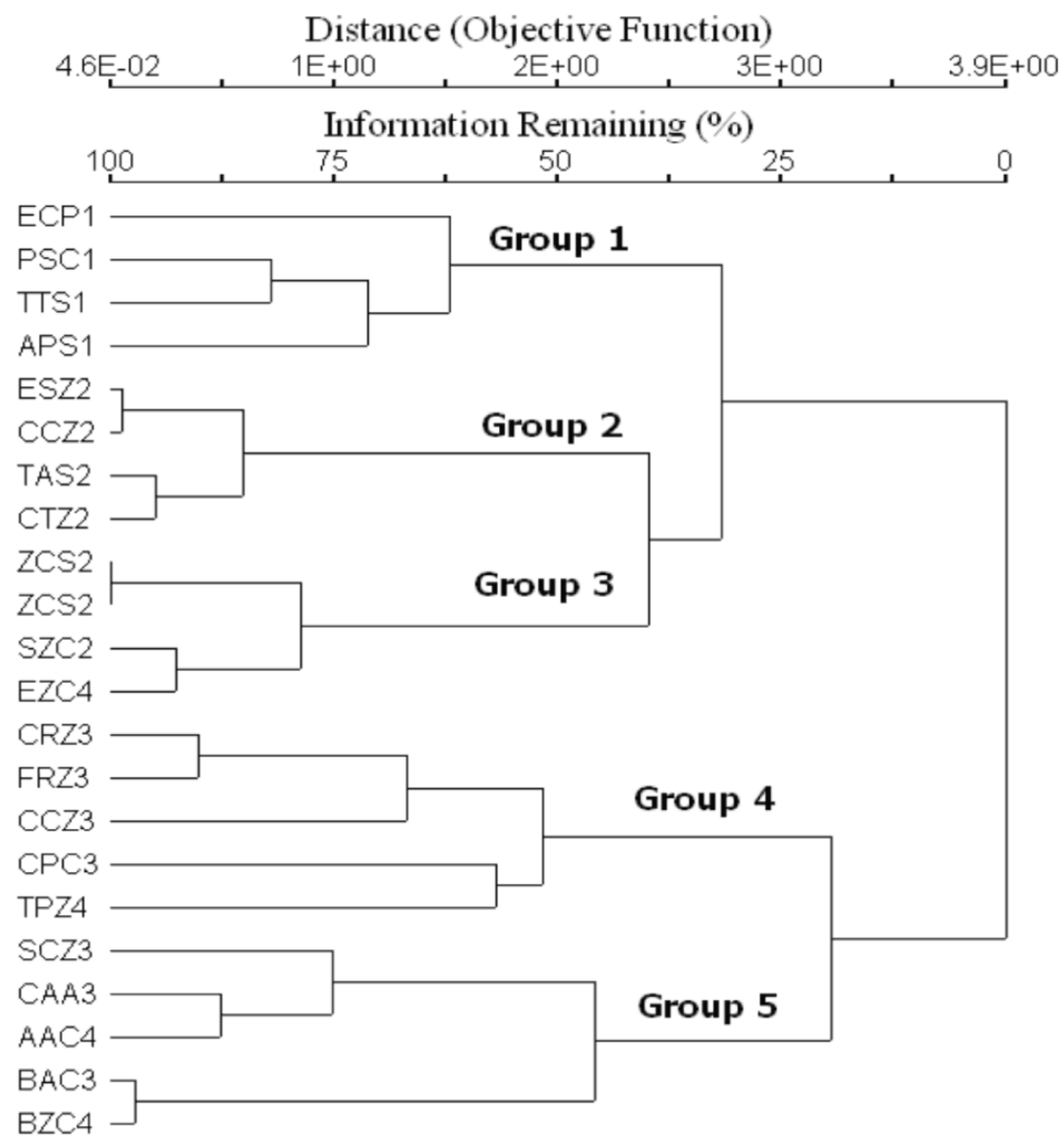

Figure 2. Two way cluster dendrogram showing grouping of different communities into association, Tehsil Takht-e-Nasrati, Karak.

\section{DISCUSSION}

Cluster analysis segregates the communities of similar character into major groups of plant life. In summer, 5 groups were structured. The chaining percentage would be high with high quantity and presence of species in an area. In summer, species presence is restricted to specific area due to diverse factors. Grazing, plants cutting, non availability of water, soil erosion and uprooting of plant species are most problems in the investigated area. Ahmed and Yasmin (2011) using DECORANA, analyzed natural vegetation of two zones along Hanna Lake, Balu- chistan and classified the vegetation. Major group is the aimed to give structure to plant life. However, cluster analysis is a helpful preliminary position for competent judgment and adjoining neighbors of vegetation. The greater the homogeneity within communities, the greater will be the similarity in the clustering (Khan and Hussain, 2012). The cluster analysis was used to give clear picture of the plant life in an area in the form of tree-shape. In hierarchical clustering, the principle is to structure a hierarchical chain of plant species and communities' groups sorting from groups of plant and community position at the bottom to a comprehensive group at the top. 
summer

\begin{tabular}{|c|c|c|c|c|}
\hline \multicolumn{5}{|c|}{ Distance (Objective Function) } \\
\hline 은 & $2.9 \mathrm{E}+00$ & $5.7 E+00$ & $8.6 \mathrm{E}+00$ & $1.1 \mathrm{E}+0$ \\
\hline \multicolumn{5}{|c|}{ Information Remaining (\%) } \\
\hline 100 & 75 & 50 & 25 & 0 \\
\hline
\end{tabular}

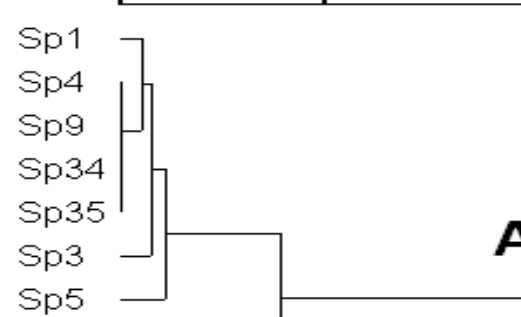

Sp8 7

Sp16

Sp10

Sp14

Sp26

Sp29

Sp40

Sp25

Sp36

Sp44

Sp41

B

Sp15

Sp46

Sp2

Sp6 6

$\mathrm{Sp} 23$

Sp21

Sp12

$\mathrm{Sp} 27$

Sp43

Sp11

Sp22

Sp13

Sp18

Sp24

Sp19-

Sp28

Sp45

Sp7

$\mathrm{Sp} 2 \mathrm{O}$

Sp38

Sp17

A

Sp30

Sp33

Sp37

Sp42

Sp31

Sp32

Sp39

Figure 3. Two way cluster dendrogram showing grouping of different plant species into association, Tehsil Takht-e-Nasrati, Karak. 


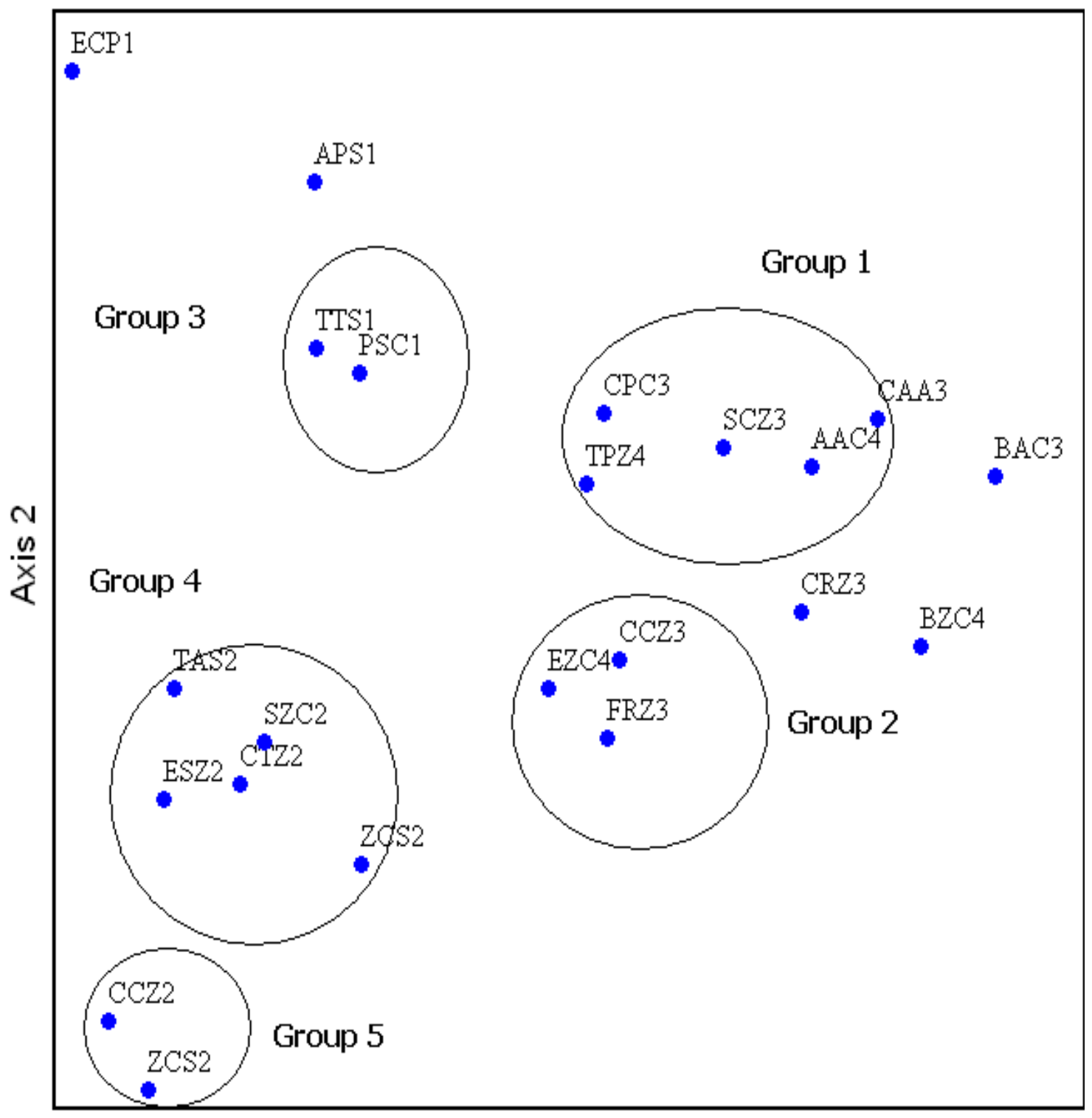

\section{Axis 1}

Figure 4. Detrended Correspondence Analysis (DCA) of communities during summer, Tehsil Takht-eNasrati, Karak.

The graphical diagram which represents the hierarchy in the structure of upturned tree expresses a dendogram that clarifies the arrangement in which positions were united (bottom-up outlook) or group were divided (top-down outlook).

DCA was used to give the shape to the communities on the basis of weight. This method is also used to give clear picture of plant life in specific areas in different seasons. The present results concluded that the plant species composition was different in different seasons in the same area. On Axis 1, the DCA weight was low in plain area because plants are restricted to specific sites due to environmental condition. However, DCA has limi- tations, making it best to remove extreme outliers and discontinuities prior analysis. DCA consistently gives the most interpretable ordination results, but as always, the interpretation of results remains a matter of ecological insight and is improved by field experience and by integration of supplementary environmental data for the plant life sample sites. Ali and Malik (2010) applied the DCA to identify environmental gradients to define vegetation distribution in green belts, gardens and parks of Islamabad city and classified the flora into 4 major association groups. El-Ghanim et al. (2010) studied the vegetation at Hail region north of central Saudi Arabia where multivariate techniques results showed 7 vegetation groups. 


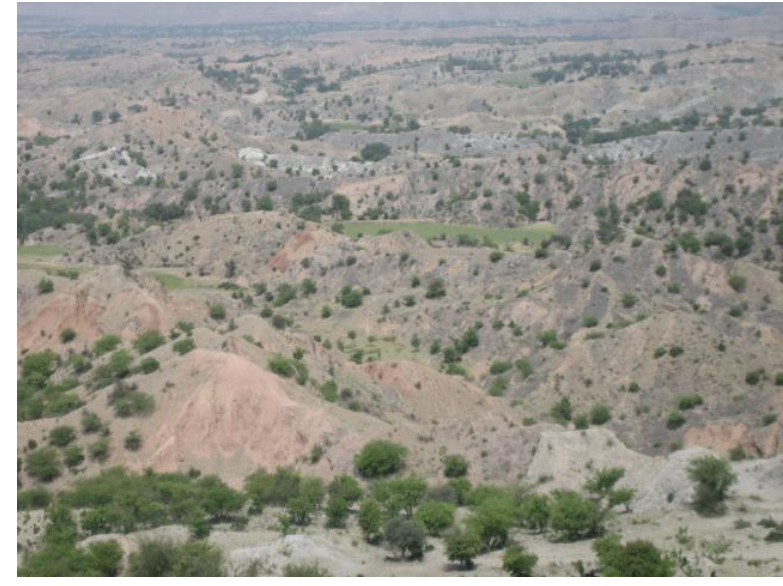

Figure 5. A view of Kandu Khel.

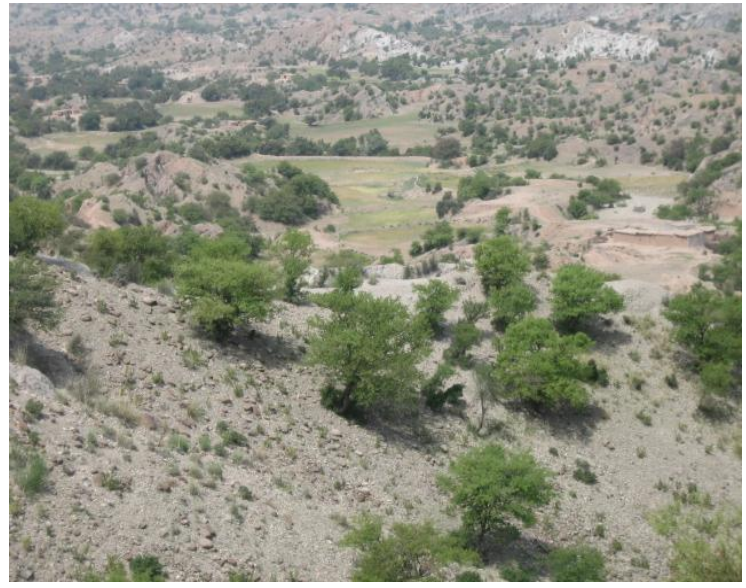

Figure 6. A view of Serki Lawager.

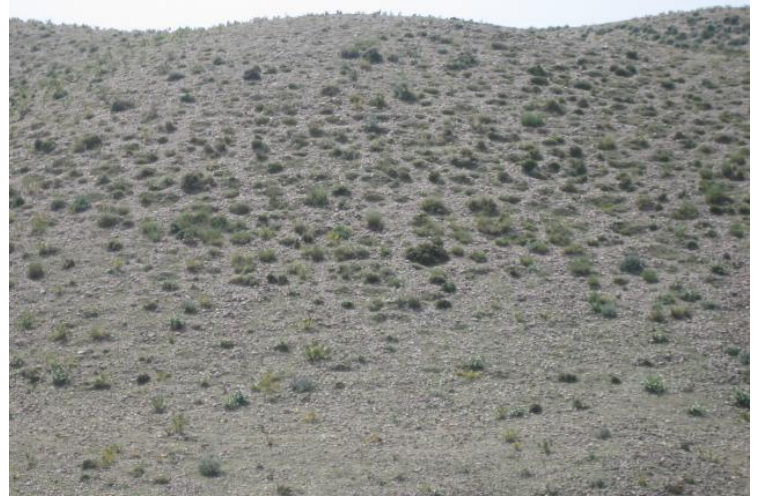

Figure 7. Cymbopogon jwarancusa vegetation.

Ahmad et al. (2010b) analyzed the vegetation along motorway (M-2), Pakistan by using multivariate techniques. Jongman et al. (1995) recommended that if plants species or communities turnover is larger than 1.9 stand-

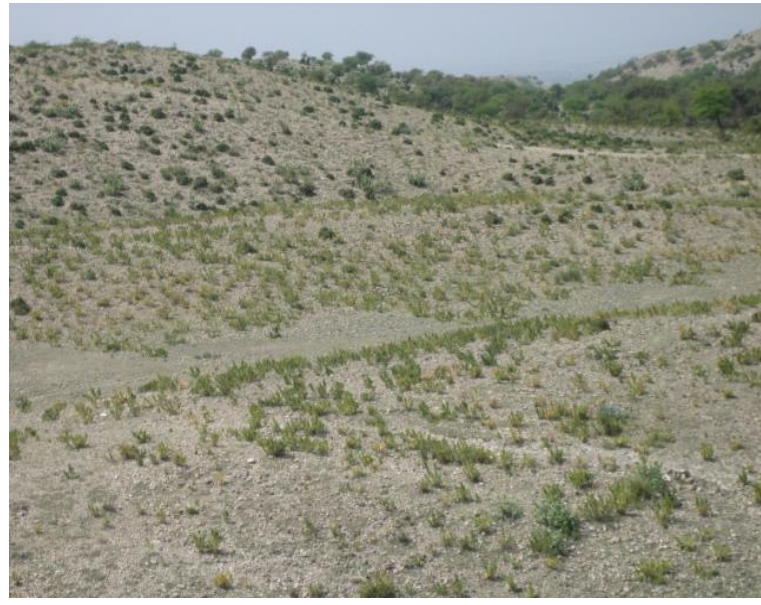

Figure 8. Rhazya stricta vegetation.

ard deviation, then DCA technique is advanced option of ordination. DCA was carried out to express compositional ascents in the plant life. DCA was presented using a default value for rescaling and detrending. Rare species and divergent communities were down weighted in DCA ordination. The different association produced by cluster analyses in different seasons is designed as the first two axes as a sprinkled diagram. The DCA ordination axes may signify the same way the main substrate weight that affect the community in these records which have been used by the community and area characteristic of the relationship to argue the dominant characteristics of the location and plant life association. Cluster and DCA analysis are very helpful in communities' and species classification in addition to give structure to plant life. Such type of study was also carried out by Saima et al. (2009) who stated that tree density, $\mathrm{pH}$ and soil texture were the major determinant of vegetation pattern. There was thin vegetation in the investigated area and species was present in patches (Khan, 2012) (Figures 5 and 6). The ecologists have tried to quantify the division of species beside the ecological gradients. There is an association between plant life sample and resources available (Ahmad et al., 2009b; Jabeen and Ahmad, 2009; Khan and Hussain, 2013a, b; Khan et al., 2013).

Our result agrees with that of Dasti and Malik (1998) who stated that altitude is an environmental factor which affects plants association. Plant ecologists have commonly been aware of the fact that plant life shows inconsistency over a wide range of particular scales and area that have built up methods for studying the classification of vegetation. The area show less rainfall than $200 \mathrm{~mm}$ and consist of thorny trees like Zizyphus spp., Acacia nilotica and Acacia modesta (Figures 7 and 8). Trees are sprinkled, roots are long, leaves are thick and small in most plant species; therefore, the investigated area fall into tropical thorn forests. The value of altitude as an ecological factor affecting plant species association is not considered surprising, because of its close correlation 
with precipitation and interruption of rain (Danin et al., 1975; Evenari et al., 1982). Malik and Hussain (2008) conducted a study to work out the relationship between remote sensing data and vegetation communities of ecological importance using multivariate techniques and stated that the ordination methods proved effective in summarizing basic, general structure of the plant community types and to some extent indicated correspondence with their spectral signatures. This study pointed out that the climatic environment of the region has restricted enlistment of area and the plant life was changed with the change of seasons and altitude.

\section{Conclusion}

Multivariate techniques methods are used as a perfect way to study and help skillfully in evaluating the biodiversity and conservation of intact habitat and plant life in specific areas. This study pointed out that climatic environment of the region has privileged conscription of area and association of plant was changed with the change of altitude. Plant ecologists have commonly been conscious that vegetation shows a discrepancy over a broad variety of particular scales and area. Therefore, it is necessary that we apply the multivariate techniques methods for studying the degree of plant life distinction.

\section{ACKNOWLEDGEMENTS}

This paper is a portion of $\mathrm{PhD}$ thesis published as mandatory for the awarding of $\mathrm{PhD}$ degree. The authors are grateful to the local people of the area who gave information about plant species and assistance.

\section{REFERENCES}

Ahmad SS (2009). Ordination and classification of herbaceous vegetation in Margalla Hills National Park Islamabad Pakistan, Biological Diversity and Conservation, Bio. Di. Con. 2(2): 38-44.

Ahmad SS, Fazal S, Valeem EE, Zafar I (2009). Evaluation of ecological aspects of road side vegetation around Havalian city using multivariate techniques. Pak. J. Bot. 41(1):461-466.

Ahmad SS, Wahid A, Akbar KF (2010). Multivariate classification and data analysis of vegetation along motorway (M-2), Pakistan. Pak. J. Bot. 42(2):1173-1185.

Ali SM, Malik RN (2010). Spatial Patterns Of Vegetation With Underlying Soil Properties Prevailing Along Drain Side Areas In Islamabad City. Pak. J. Bot. 42(4):2397-2410.

Dasti AA, Malik SA (1998). A transect of vegetation and soils on the Indus valley scarp slope, Pakistan. Pak J. Plant Sci. 4(2):73-84.

El-Bana M, Shaltout K, Khalafallah A, Mosallam H (2009). Ecological status of the Mediterranean Juniperus phoenicea L., relicts in the desert mountains of North Sinai, Egypt. Flora - Morphology, Distribution, Functional Ecology of Plants.

El-Ghanim WM, Hassan LM, Galal TM, Badr A (2010). Floristic composition and vegetation analysis in Hail region north of central Saudi Arabia. Saudi J. Biol. Sci. 17:119-128.

He MZ, Zheng JG, Li XR, Qian YL (2007). Environmental factors affecting vegetation composition in the Alxa Plateau, China, J. Arid Environ. Pp. 473-489.
Hill MO (1979). TWINSPAN - a FORTRAN Programme for Arranging Multivariate Data in an Ordered Two-Way Table By Classification of the Individuals and Attributes. Cornell University, Department of Ecology and Systematic, Ithaca, New York.

Hussain F (1989). Field and Laboratory Manual of Plant Ecology. UGC. Islamabad.

Jabeen T, Ahmad SS (2009). Multivariate analysis of environmental and vegetation data of Ayub National Park, Rawalpindi. Soil and Environment. 28(2):106-112.

Khan M (2012). Dimension and Composition of plant life in Tehsil Takhte-Nasrati, district Karak, Khyber Pakhtunkhawa, Pakistan. Ph.D. thesis, Department of Botany, University of Peshawar, Khyber Pakhtunkhawa, Pakistan.

Khan M (2004). A Fraction of the Angiosperms of Tehsil Banda Daud Shah." M.Sc thesis. Gomal University D. I. Khan, Khyber Pakhtunkhawa, Pakistan.

Khan M, Hussain F (2012). Plant Life Classification in Winter of Tehsil Takht-E-Nasrati, District Karak, Khyber Pakhtunkhawa, Pakistan. ARPN J. Sci. Technol. 2:113-123.

Khan M, Hussain F, Musharaf S (2013). Biodiversity of plant species in Tehsil Takht-e-Nasrati, Pakistan. International J. Biodiv. Conserv. 5(1):39-46.

Khan M, Hussain F (2013a). Conservation status of plant species in Tehsil Takht-e-Nasrati, District Karak, Khyber Pakhtunkhawa, Pakistan. International J. Biodiv. Conserv. 5(1):20-26.

Khan M, Hussain F (2013b). Altitudinal Effect on Plant Life Structure in Plains of Tehsil Takht-E-Nasrati, District Karak, Pakistan. Global J. Sci. Frontier Res. 13(1):19-34.

Khaznadar M, Vogiatzakis IN, Griffiths GH (2009). Land degradation and vegetation distribution in Chott El Beida wetland, Algeria. J. Arid Environ. 73(3):369-377.

Malik RN, Husain SZ (2008). Linking remote sensing and ecological vegetation communities: a multivariate approach. Pak. J. Bot. 40(1):337-349.

McCune B, Mefford MJ (1999). Multivariate analysis of ecological data. Version 4.16. MJM software, Oregon, USA.

Nasir E, Ali SI (eds.) (1972). Flora of West Pakistan. Fakhri Press, Karachi.

Sagers LC, Lyon J (1997). Gradient analysis in a riparian landscape: contrasts among forest layers. Forest Ecology and Management. 96:13-26.

Saima S, Dasti AA, Hussain F, Wazir SM, Malik SA (2009). Floristic compositions along an 18 - km long transect in ayubia National Park district Abbottabad, Pakistan. Pak. J. Bot. 41(5):2115-2127.

Stewart RR (1972). An Annotated Catalogue of the Vascular Plants of West Pakistan and Kashmir.Gordon College, Rawalpindi. 